\title{
Propofol protects against high glucose-induced endothelial adhesion molecules expression in human umbilical vein endothelial cells
}

\author{
Minmin Zhu $^{\dagger}$, Jiawei Chen ${ }^{\dagger}$, Hui Jiang and Changhong Miao ${ }^{*}$
}

\begin{abstract}
Background: Hyperglycemia could induce oxidative stress, activate transcription factor nuclear factor kappa B (NF-kB), up-regulate expression of endothelial adhesion molecules, and lead to endothelial injury. Studies have indicated that propofol could attenuate oxidative stress and suppress NF-KB activation in some situations. In the present study, we examined whether and how propofol improved high glucose-induced up-regulation of endothelial adhesion molecules in human umbilical vein endothelial cells (HUVECs).

Methods: Protein expression of endothelial adhesion molecules, NF-KB, inhibitory subunit of NF-kBa (IKBa), protein kinase C $\beta 2$ (PKC 32 ), and phosphorylation of PKC 32 (Ser ${ }^{660}$ ) were measured by Western blot. NF-KB activity was measured by electrophoretic mobility shift assay. PKC activity was measured with SignaTECT PKC assay system. Superoxide anion $\left(\mathrm{O}_{2}^{-}\right)$accumulation was measured with the reduction of ferricytochrome $\mathrm{c}$ assay. Human peripheral mononuclear cells were prepared with Histopaque-1077 solution.

Results: High glucose induced the expression of endothelial selectin (E-selectin), intercellular adhesion molecule 1 (ICAM-1), vascular cell adhesion molecule 1 (VCAM-1), and increased mononuclear-endothelial adhesion. High glucose induced $\mathrm{O}_{2}^{-}$accumulation, PKC 32 phosphorylation and PKC activation. Further, high glucose decreased IkBa expression in cytoplasm, increased the translocation of NF-kB from cytoplasm to nuclear, and induced NF-KB activation. Importantly, we found these high glucose-mediated effects were attenuated by propofol pretreatment. Moreover, CGP53353, a selective PKC 32 inhibitor, decreased high glucose-induced NF-KB activation, adhesion molecules expression, and mononuclear-endothelial adhesion.

Conclusion: Propofol, via decreasing $\mathrm{O}_{2}^{-}$accumulation, down-regulating PKC $32 \mathrm{Ser}^{660}$ phosphorylation and PKC as well as NF-kB activity, attenuated high glucose-induced endothelial adhesion molecules expression and mononuclear-endothelial adhesion.
\end{abstract}

Keywords: Propofol, High glucose, Adhesion molecules, NF-kB, HUVECS

\section{Background}

Perioperative hyperglycemia, a metabolic alteration caused by perioperative physiological stress and excessive glucose infusion, was commonly seen in non-diabetics [1] as well as diabetics [2]. Hyperglycemia could up-regulate the expression of endothelial adhesion molecules, such as endothelial selectin (E-selectin), intercellular adhesion molecule 1 (ICAM-1), and vascular cell adhesion molecule 1

\footnotetext{
* Correspondence: 09211230020@fudan.edu.com

${ }^{\dagger}$ Equal contributors

Department of Anaesthesiology and Oncology, Shanghai Medical College Fudan University Shanghai Cancer Centre, Shanghai, People's Republic of China
} endothelial adhesion [3] and leading to endothelial dysfunction and injury. Accordingly, during perioperative period, especially for hyperglycemic patients, interventions that may inhibit endothelial adhesion molecules expression are potential strategies to protect endothelial cells from dysfunction and its sequelae.

Hyperglycemia could induce overproduction of reactive oxygen species (ROS), which is one of the major factors responsible for diabetic vascular injury [6,7]. The nuclear factor kappa B (NF- $\mathrm{kB}$ ) signal pathway was also reported to be involved in high glucose-induced up- 
regulation of endothelial adhesion molecules $[3,8]$. Lee et al. and Kwon et al. reported that high glucose-induced up-regulation of endothelial adhesion molecules was alleviated by inhibiting ROS generation and NF- $\mathrm{kB}$ activity $[8,9]$. Propofol (2, 6-diisopropylphenol) is a widely used intravenous anesthetic agent. Chen J et al. found propofol could suppress oxidative stress, NF- $\mathrm{kB}$ activation and mononuclear-endothelial adhesion in endothelial cells exposed to hydrogen peroxide [10]. However, the protective effects of propofol on hyperglycemia-induced expression of endothelial adhesion molecules have not been well studied. In the present study, we examined whether propofol improved high glucose-induced up-regulation of endothelial adhesion molecules and mononuclear-endothelial adhesion in human umbilical vein endothelial cells (HUVECs). More importantly, we explored the potential underlying mechanisms.

\section{Methods}

\section{Cell culture}

HUVECs (Clonetics) were grown in Dulbecco's modified Eagle medium (DMEM) with $5 \mathrm{mM}$ glucose and $10 \%$ fetal bovine serum. Cells were cultured in an incubator supplemented with $5 \% \mathrm{CO}_{2}-95 \%$ air at $37^{\circ} \mathrm{C}$ and sub-cultured on reaching $90 \%$ confluence. The fourth passage of cells was employed in this study.

\section{Study design}

HUVECs were cultured with different concentrations (5, $10,15,20$ and $30 \mathrm{mM})$ of glucose for different times $(1,2,4$ and $8 \mathrm{~h}$ ). By measuring adhesion molecules expression, we determined the appropriate glucose treatment condition with maximal effect on endothelial adhesion molecules expression. During general anesthesia, plasma concentrations of propofol range from 5 to $50 \mathrm{uM}$ [11]. To mimic in vivo situations, HUVECs were pre-incubated with different concentrations (5, 10, 20, and 40uM) of propofol (Sigma) for $30 \mathrm{~min}$, followed by glucose treatment. The optimal concentration of propofol with significant inhibitory effects on endothelial adhesion molecules expression was determined. These treatment conditions were used in the subsequent studies in which HUVECs were cultured and divided into four groups to examine the underlying signaling pathways. Group 1: HUVECs were cultured in $5 \mathrm{mM}$ glucose for $4 \mathrm{~h}$ as control; Group 2: HUVECs were pre-incubated with 10uM propofol for $30 \mathrm{~min}$ and treated with $5 \mathrm{mM}$ glucose for $4 \mathrm{~h}$; Group 3: HUVECs were treated with $15 \mathrm{mM}$ glucose for $4 \mathrm{~h}$; Group 4: HUVECs were pre-incubated with $10 \mathrm{uM}$ propofol for $30 \mathrm{~min}$ and treated with $15 \mathrm{mM}$ glucose for $4 \mathrm{~h}$.

\section{Western blot analysis}

Whole-cell extracts, nuclear extracts and cytoplasmic extracts were prepared with the use of Nuclear Extract Kit (Active Motif) according to the manufacturer's instructions. Equal amounts of protein were separated by $6 \%$ or 8\% SDS-PAGE and transferred to PVDF membranes. After being blocked in 5\% skim milk, the membranes were incubated with an appropriate dilution of primary antibody at $4^{\circ} \mathrm{C}$ for overnight. The primary antibodies were monoclonal antibody against E-selectin (Santa Cruz Biotechnology), protein kinase $\mathrm{C} \beta 2$ (РКC $\beta 2)$ (Abcam), Phospho-PKC $\beta 2\left(\operatorname{ser}^{660}\right)($ Abcam), $\beta$-actin (Santa Cruz Biotechnology), and polyclonal antibody against ICAM-1

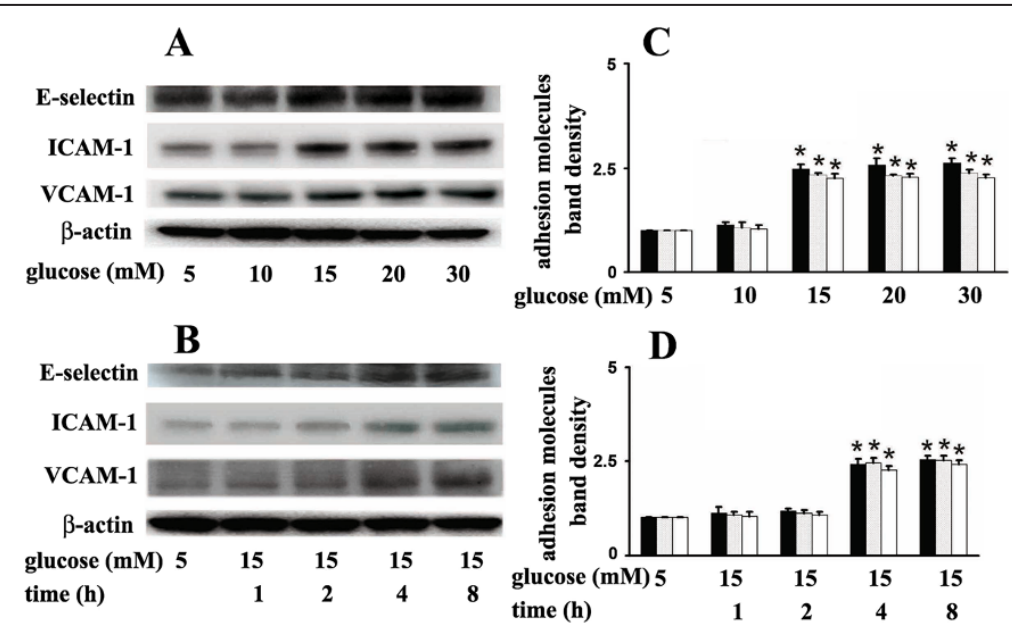

Figure 1 Effects of glucose on adhesion molecules expression in human umbilical vein endothelial cells (HUVECs). (A) HUVECS were cultured in different concentrations of glucose $(5,10,15,20,30 \mathrm{mM})$ for 4 hours. (B) HUVECs were cultured in $5 \mathrm{mM}$ or $15 \mathrm{mM}$ glucose for different times (1, 2, 4, 8 h). (C, D) Quantification of protein band density of adhesion molecules $\left({ }^{*} p<0.05\right.$ vs. 5 mM glucose, $\left.n=5\right)$. Data were expressed as mean \pm SD. . represents E-selectin, $\%$ represents ICAM-1, $\square$ represents VCAM-1. 


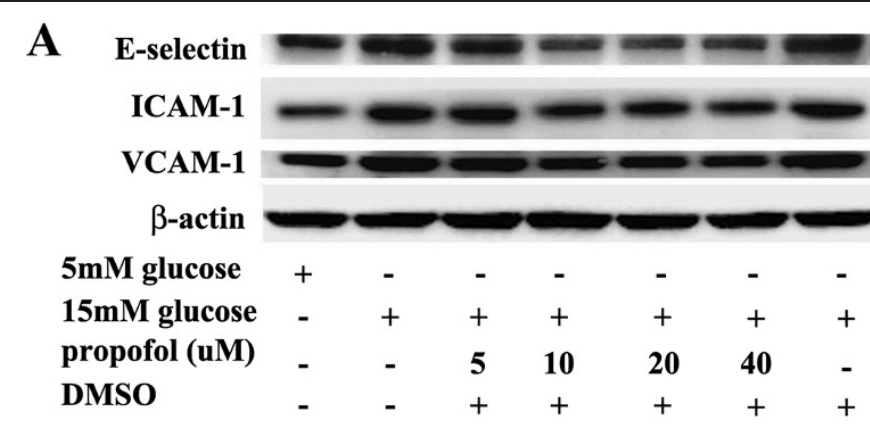

\section{B}

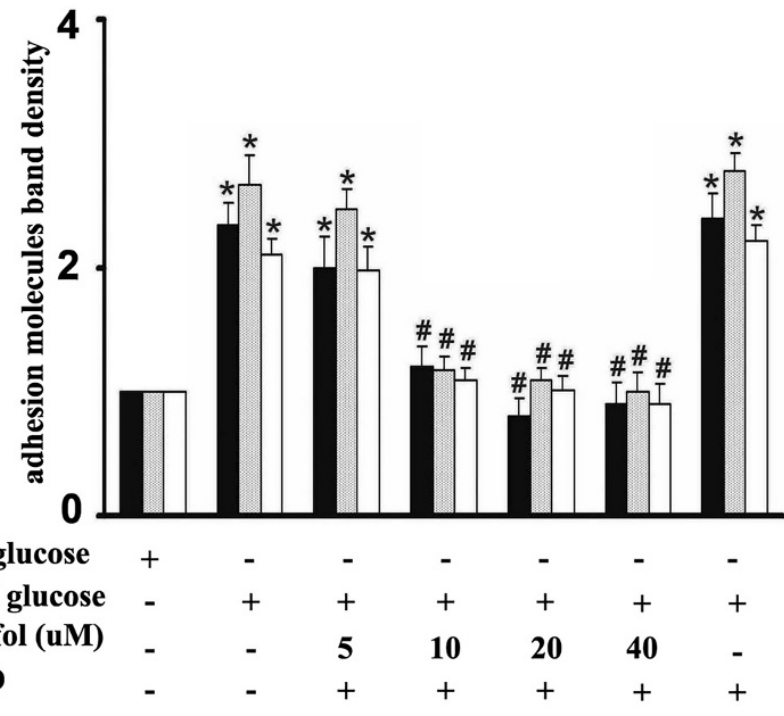

C

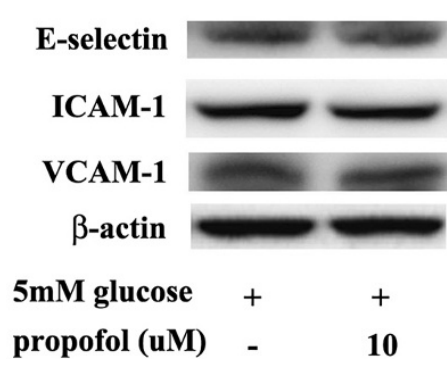

D

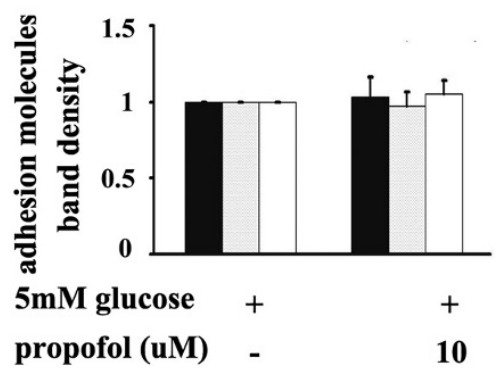

Figure 2 Effects of propofol on adhesion molecules expression in hyperglycemic human umbilical vein endothelial cells (HUVECs).

(A) HUVECs were pre-incubated with different concentrations (5, 10, 20, and 40uM) of propofol for 30 min, followed by glucose treatment.

(B) Quantification of protein band density of adhesion molecules ( ${ }^{*} \mathrm{p}<0.05$ vs. $5 \mathrm{mM}$ glucose, $\# p<0.05$ vs. $15 \mathrm{mM}$ glucose, $\left.n=5\right)$. (C) HUVECs were pre-incubated with $10 \mathrm{uM}$ propofol for $30 \mathrm{~min}$, followed by $5 \mathrm{mM}$ glucose treatment. (D) Quantification of protein band density of adhesion molecules ( ${ }^{*} p<0.05$ vs. 5 mM glucose, \#p $<0.05$ vs. $15 \mathrm{mM}$ glucose, $n=5$ ). Data were expressed as mean $\pm S D$. m represents E-selectin,

represents ICAM-1, $\square$ represents VCAM-1.

(Cell Signaling Technology),VCAM-1 (Santa Cruz Biotechnology), NF-кB p65 (Cell Signaling Technology), inhibitory subunit of nuclear factor- $\kappa \mathrm{B} \alpha(\mathrm{I} \kappa \mathrm{B} \alpha)$ (Santa Cruz Biotechnology), Histone H3 (Santa Cruz Biotechnology). Then, the membranes were incubated with secondary antibody, washed, and detected with the ECL system. The relative densities of protein bands were analyzed by Scangel-it software.
PKC activity assay

PKC activity was measured with SignaTECT PKC assay system (Promega) according to the manufacturer's instructions. In brief, membrane extracts, reaction buffer (100 mM Tris-HCl, $1.6 \mathrm{mg} / \mathrm{ml}$ phosphatidylserine, $0.16 \mathrm{mg} / \mathrm{ml}$ diacylglycerol, $50 \mathrm{mM} \mathrm{MgCl} 2)$ and $\left[\gamma^{-}{ }^{32} \mathrm{P}\right]$ ATP were mixed and kept at $30^{\circ} \mathrm{C}$ for $10 \mathrm{~min}$. PKC phosphorylation was determined by measuring the radioactivity. 

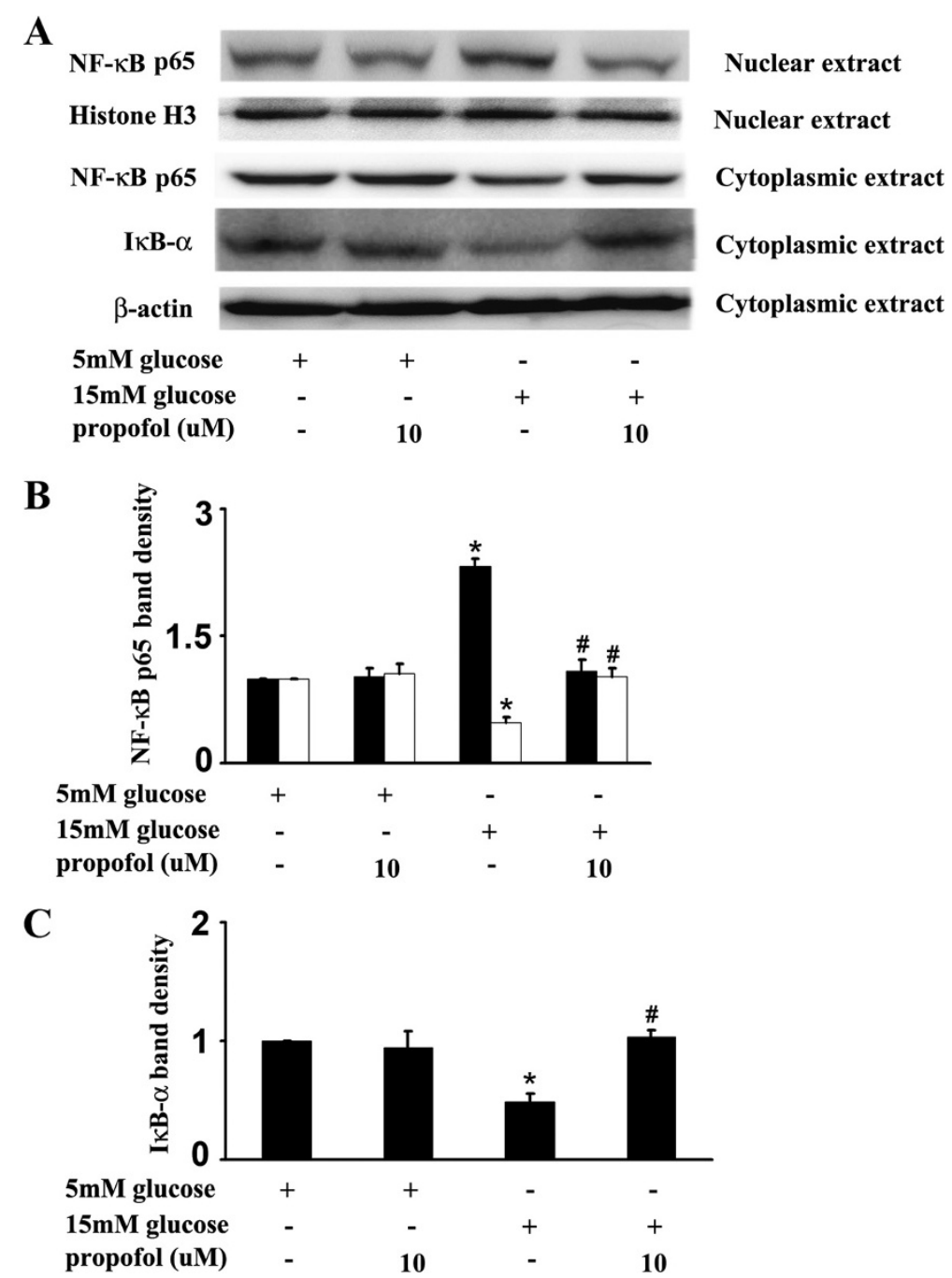

Figure 3 Effects of propofol on $15 \mathrm{mM}$ glucose-mediated nuclear factor kappa B (NF-KB) signal pathway. (A) Human umbilical vein endothelial cells were cultured in either $5 \mathrm{mM}$ glucose or $15 \mathrm{mM}$ glucose for $4 \mathrm{~h}$ with corresponding treatment. (B) Quantification of protein band density of NF-kB (p65) ( ${ }^{*} \mathrm{p}<0.05$ vs. $5 \mathrm{mM}$ glucose, $\# \mathrm{p}<0.05 \mathrm{vs.} 15 \mathrm{mM}$ glucose, $\mathrm{n}=5$ ). represents nuclear extract, $\square$ represents cytoplasmic extract. (C) Quantification of protein band density of $\mathrm{IkBa}\left({ }^{*} \mathrm{p}<0.05 \mathrm{vs} .5 \mathrm{mM}\right.$ glucose, $\# \mathrm{p}<0.05 \mathrm{vs} .15 \mathrm{mM}$ glucose, $\left.\mathrm{n}=5\right)$. Data were shown as mean \pm SD.

The enzymatic activity of PKC was determined by subtracting the activity of the enzyme in the absence of phospholipids from that of the enzyme in the presence of phospholipids. The results were shown as folds increased compared with $5 \mathrm{mM}$ glucose group.

\section{Electrophoretic mobility shift assay}

NF- $\mathrm{kB}$ activity was measured by electrophoretic mobility shift assay as described previously [10]. In brief, $\left[\gamma^{-32} \mathrm{P}\right]$ ATP (Amersham Life Sciences) was used to end-label the complementary oligonucleotides containing NF- $\mathrm{kB}$ binding site (5'-TGTCGAATGCAAATCACTAGAA-3'), and QIAquick Nucleotide Removal Kit (Qiagene) was use to eliminate the unincorporated $\left[\gamma^{-}{ }^{32} \mathrm{P}\right]$ ATP. The radiolabeled probes and nuclear extracts were incubated together for $30 \mathrm{~min}$. For supershift assay, $5 \mu \mathrm{g}$ rabbit polyclonal antibody against NF-kB (Santa Cruz Biotechnology) was mixed with nuclear extracts on ice for $1 \mathrm{~h}$ before the addition of radiolabeled probes. The specificity was verified by supershift assay with $5 \mu \mathrm{g}$ normal rabbit IgG (Santa Cruz Biotechnology). For competition assay, 100-fold excess of nonradiolabeled probes were incubated with nuclear extracts for $10 \mathrm{~min}$ before the addition of radiolabeled probes. As negative control for competition assay, 100-fold excess of nonradiolabeled probes containing a mutant NF- $\mathrm{KB}$ binding site (5'-TGTCGAATGCAAGCCACTAG AA-3') were used as competitors. The DNA-protein complexes were separated by electrophoresis in a $6 \%$ non-denaturing polyacrylamide 


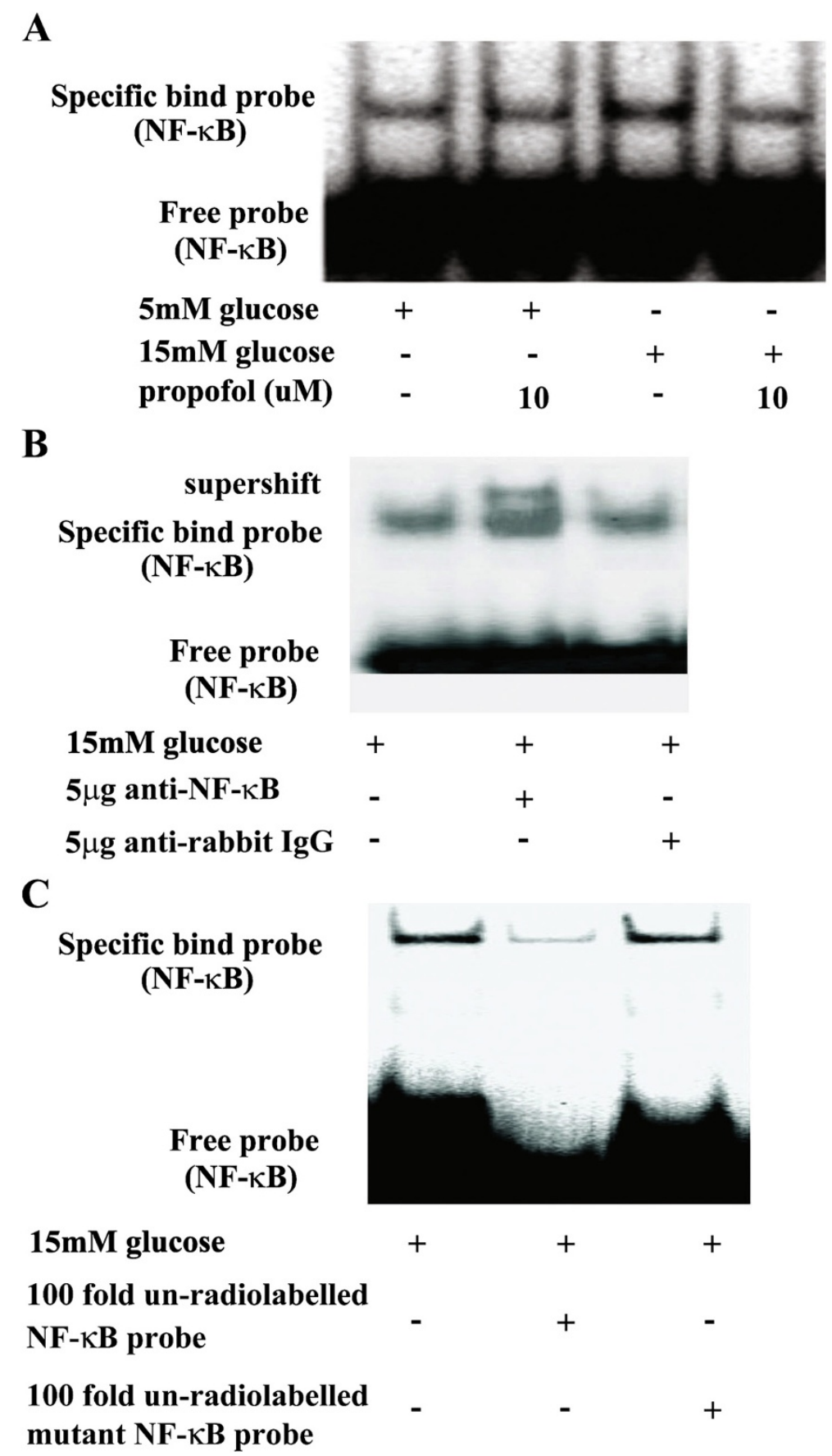

Figure 4 Effects of propofol on 15 mM glucose-induced nuclear factor kappa B (NF-kB) activation. (A) Human umbilical vein endothelial cells were cultured in either $5 \mathrm{mM}$ glucose or $15 \mathrm{mM}$ glucose for $4 \mathrm{~h}$ with corresponding treatment. Shifted band was increased by $15 \mathrm{mM}$ glucose, but reduced by propofol $(n=5)$. (B) In the supershift assay, $15 \mathrm{mM}$ glucose-induced band was shifted by the pre-incubation of nuclear extracts with anti-NF-kB antibody, but was not affected by normal rabbit lgG $(n=5)$. (C) In the competition assay, 100-fold excess of nonradiolabeled probes were incubated with nuclear extracts $10 \mathrm{~min}$ before the addition of radiolabeled probes. $15 \mathrm{mM}$ glucose-induced shifted band was blocked by nonradiolabeled competitors, but mutant competitors had no such effect $(n=5)$. 

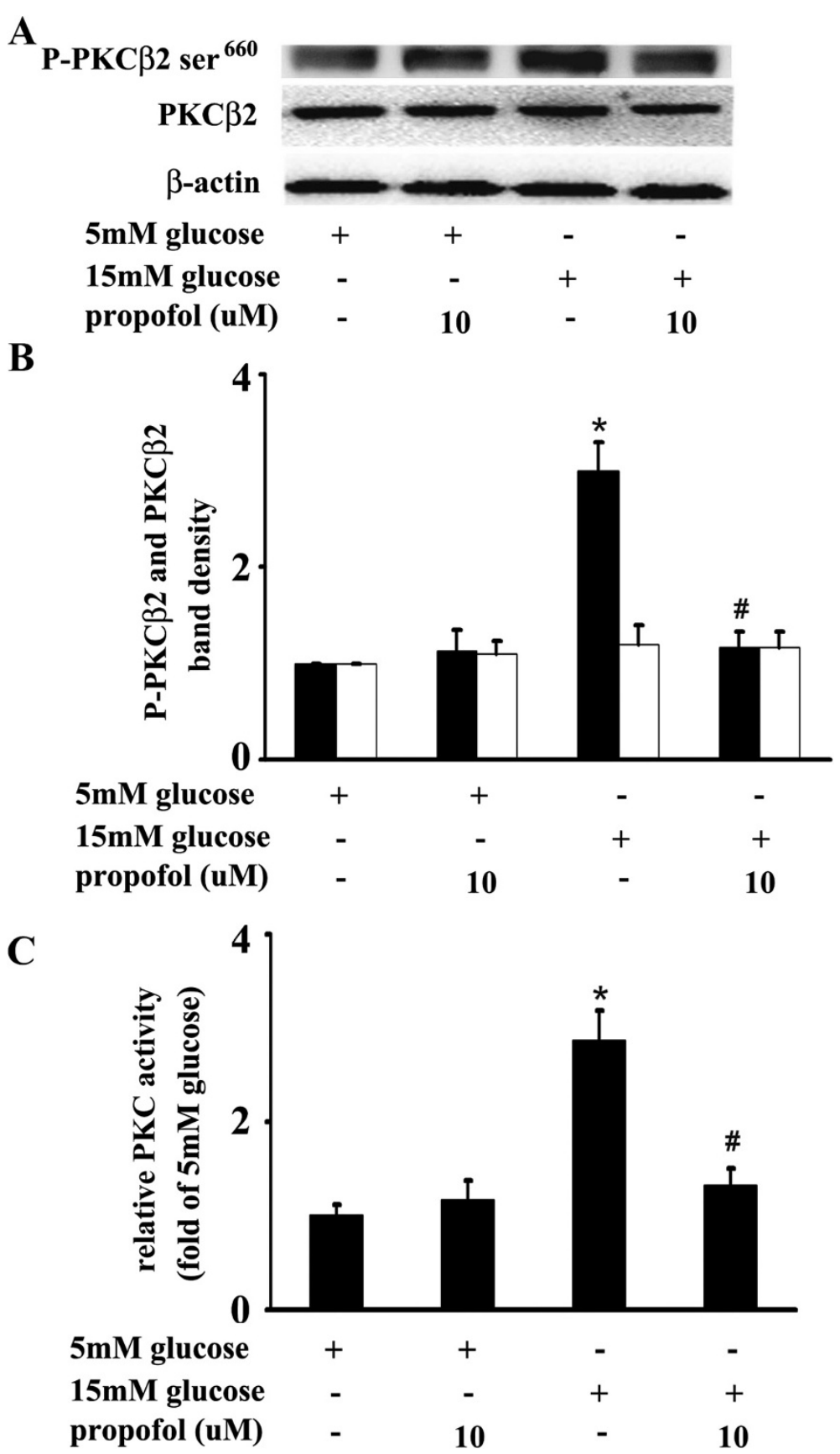

Figure 5 Effects of propofol on $15 \mathrm{mM}$ glucose-induced $\mathrm{Ser}^{660}$ phosphorylation of protein kinase C $\beta 2$ (PKC 32 ) and PKC activation. (A) Human umbilical vein endothelial cells (HUVECs) were cultured in either $5 \mathrm{mM}$ glucose or $15 \mathrm{mM}$ glucose for $4 \mathrm{~h}$ with corresponding treatment. (B) Quantification of protein band density of PKC $\beta 2$ or phosphorylated PKC $\beta 2$ ( ${ }^{*} \mathrm{p}<0.05$ vs. $5 \mathrm{mM}$ glucose, \#p $<0.05$ vs. $15 \mathrm{mM}$ glucose, $n=5)$. represents PKC 32 phosphorylation, $\square$ represents PKC $\beta 2$. (C) HUVECs were cultured in either 5 mM glucose or 15 mM glucose for $4 \mathrm{~h}$ with corresponding treatment. ( ${ }^{*} p<0.05$ vs. $5 \mathrm{mM}$ glucose, $\# p<0.05$ vs. $15 \mathrm{mM}$ glucose, $n=5$ ). The results were shown as folds increased compared with $5 \mathrm{mM}$ glucose group. 


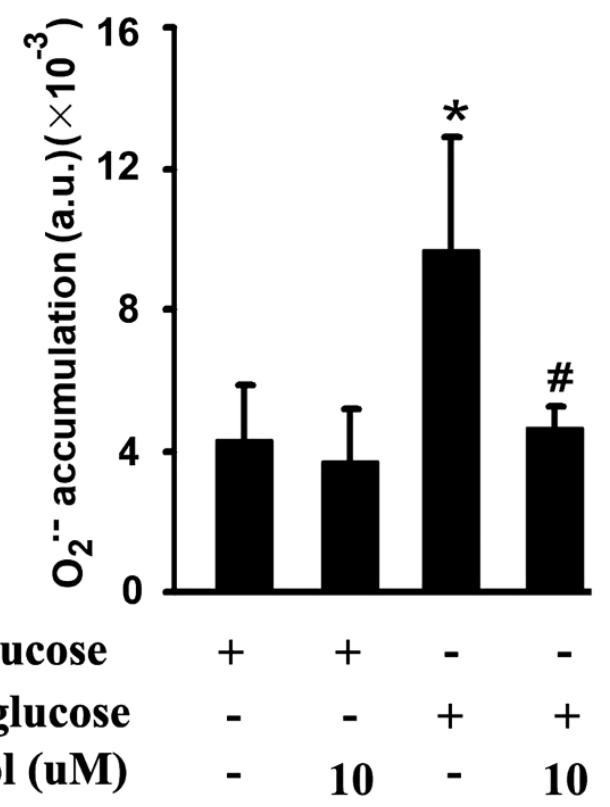

Figure 6 Effects of propofol on $15 \mathrm{mM}$ glucose-induced superoxide anion $\left(\mathrm{O}_{2}^{-}\right)$accumulation. Human umbilical vein endothelial cells were cultured in either $5 \mathrm{mM}$ glucose or $15 \mathrm{mM}$ glucose for $4 \mathrm{~h}$ with corresponding treatment. ${ }^{*} \mathrm{p}<0.05$ vs. $5 \mathrm{mM}$ glucose, \#p $<0.05$ vs. $15 \mathrm{mM}$ glucose, $n=5)$. Data were shown as mean \pm SD. (a.u. $=$ arbitrary units).

gel. The gels were dried for $1 \mathrm{~h}$, and exposed to a radiographic film for $24 \mathrm{~h}$ at $-80^{\circ} \mathrm{C}$.

\section{Superoxide anion $\left(\mathrm{O}_{2}^{-}\right)$accumulation assay}

$\mathrm{O}_{2}^{-}$accumulation was measured by the reduction of ferricytochrome c assay as described previously [12]. Briefly, HUVECs were washed and cultured with KrebsHEPES buffer containing $20 \mu \mathrm{M}$ ferricytochrome c (Sigma) with or without superoxide dismutase (Sigma). The absorbance was read spectrophotometrically at $550 \mathrm{~nm}$. Reduction of ferricytochrome c with superoxide dismutase was subtracted from the values without superoxide dismutase.

\section{Isolation and adhesion of mononuclear cells to HUVECs}

The isolation of human peripheral mononuclear cells was prepared with the use of Histopaque-1077 (Sigma). In brief, $5 \mathrm{ml}$ heparinized blood from healthy volunteers was carefully layered onto $5 \mathrm{ml}$ Histopaque-1077. The mononuclear cells were collected after the blood was centrifuged at $400 \mathrm{~g}$ for $30 \mathrm{~min}$. Isolated mononuclear cells were then washed twice with PBS, suspended in the culture medium, and added to the HUVECs . After incubation at $37^{\circ} \mathrm{C}$ for $30 \mathrm{~min}$, cells were washed three times with PBS, and observed under a phase-contrast microscope. Adherent cells were counted in 10 different fields from three separate culture dishes. Written informed consent was obtained from the volunteers for publication of this report and any accompanying images.

\section{Statistical analysis}

Data were expressed as mean $\pm \mathrm{SD}$, and $n$ indicates number of experiments. Statistical significance was determined in multiple comparisons among independent groups of data in which analysis of variance indicated the presence of significant difference. A value of $\mathrm{p}<0.05$ was considered significant.

\section{Results}

$15 \mathrm{mM}$ glucose-induced endothelial adhesion molecules expression and its modulation by propofol

In HUVECs, compared with $5 \mathrm{mM}$ glucose treatment, high concentrations of glucose caused a marked up-regulation of adhesion molecules expression in a concentration- and time-dependent manner. Incubation of cells with $15 \mathrm{mM}$ glucose for $4 \mathrm{~h}$ caused a significant up-regulation of $\mathrm{E}$ selectin, ICAM-1 and VCAM-1 expression (Figure 1). We also found that propofol pre-treatment could attenuate $15 \mathrm{mM}$ glucose-induced adhesion molecules expression in a concentration-dependent manner. Compared with $15 \mathrm{mM}$ glucose treatment, pre-incubation of cells with $10 \mathrm{uM}$ propofol for $30 \mathrm{~min}$ significantly attenuated $15 \mathrm{mM}$ glucoseinduced adhesion molecules expression (Figure 2A, B). Propofol solvent dimethyl sulfoxide (DMSO) did not affect $15 \mathrm{mM}$ glucose-induced adhesion molecules expression (Figure 2A, B).

Please note pre-incubation of cells with $10 \mathrm{uM}$ propofol for $30 \mathrm{~min}$ had no effect on endothelial adhesion molecules expression in cells cultured in $5 \mathrm{mM}$ glucose (Figure 2C, D).

$15 \mathrm{mM}$ glucose-induced NF-кB, PKC and PKC 32 activation and its modulation by propofol

In HUVECs, compared with $5 \mathrm{mM}$ glucose treatment, $15 \mathrm{mM}$ glucose increased the expression of NF-kB p65 protein in the nuclear extracts and decreased its expression in the cytoplasmic extracts (Figure 3A, B), and these effects were alleviated by propofol pre-treatment. Consistently, compared with $5 \mathrm{mM}$ glucose treatment, $15 \mathrm{mM}$ glucose deceased $I \kappa B \alpha$ expression in the cytoplasmic extracts (Figure 3A, C), which was also recovered by propofol pretreatment (Figure 3A, C). The effect of $15 \mathrm{mM}$ glucose and propofol on NF- $\kappa$ B activity was determined by electrophoretic mobility shift assay. We found $15 \mathrm{mM}$ glucose induced NF- $\mathrm{B}$ activation, which was attenuated by propofol pretreatment (Figure 4A). The specificity was confirmed by supershift assay and competition assay (Figure 4B, C).

Compared with $5 \mathrm{mM}$ glucose treatment, $15 \mathrm{mM}$ glucose increased Ser ${ }^{660}$ phosphorylation of PKC $\beta 2$, which was attenuated by propofol. However, compared with $5 \mathrm{mM}$ glucose, $15 \mathrm{mM}$ glucose and propofol had no effect 
A

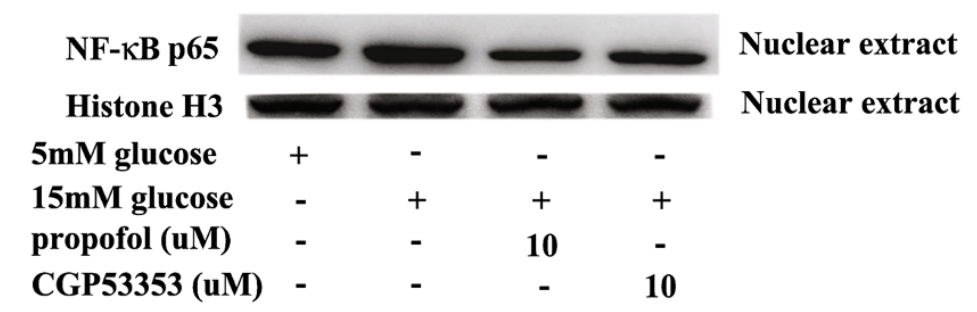

B

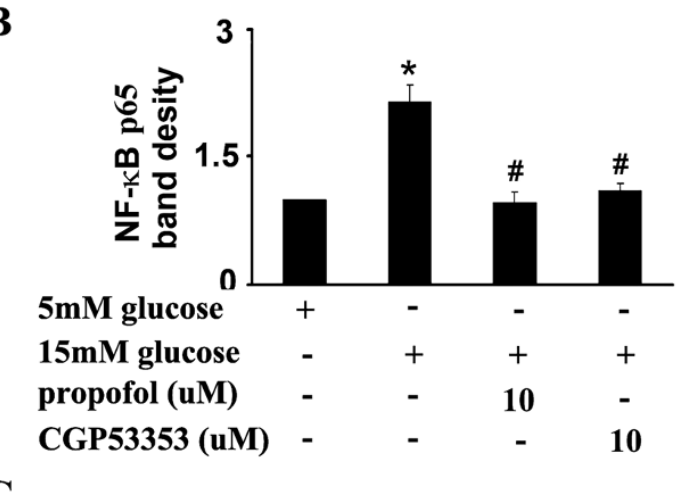

C

\section{Specific bind probe (NF-KB) \\ Non-specific bind probe (NF-kB)}
Free probe (NF-кB)

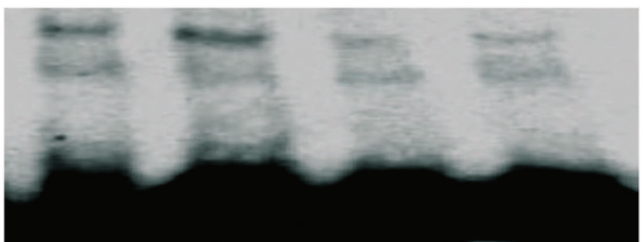

5mM glucose
$15 \mathrm{mM} \mathrm{glucose}$
propofol (uM)
CGP53353 (uM)

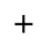

-

$-$

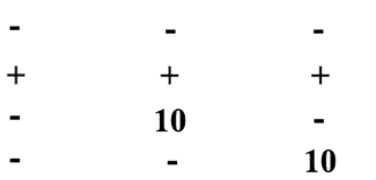

Figure 7 Effects of propofol and CGP53353 on 15 mM glucose-induced nuclear factor kappa B (NF-KB) activation. (A) Human umbilical vein endothelial cells (HUVECs) were cultured in either $5 \mathrm{mM}$ glucose or $15 \mathrm{mM}$ glucose for $4 \mathrm{~h}$ with corresponding treatment. (B) Quantification of protein band density of NF-KB (p65) ( ${ }^{*} p<0.05$ vs. $5 \mathrm{mM}$ glucose, $\# p<0.05$ vs. $15 \mathrm{mM}$ glucose, $n=5$ ). Data were shown as mean \pm SD. (C) HUVECs were cultured in either $5 \mathrm{mM}$ glucose or $15 \mathrm{mM}$ glucose for $4 \mathrm{~h}$ with corresponding treatment. Shifted band was increased by $15 \mathrm{mM}$ glucose, but reduced by propofol or CGP53353 $(n=5)$.

on PKC 32 expression (Figure 5A, B). Moreover, compared with $5 \mathrm{mM}$ glucose treatment, $15 \mathrm{mM}$ glucose induced marked PKC activation, which was attenuated by propofol (Figure 5C).

$15 \mathrm{mM}$ glucose-induced $\mathrm{O}_{2}^{--}$accumulation and its modulation by propofol

Compared with $5 \mathrm{mM}$ glucose treatment, $15 \mathrm{mM}$ glucose induced a significant increase of $\mathrm{O}_{2}^{-}$accumulation. More importantly, we found that propofol could mitigate $15 \mathrm{mM}$ glucose-induced $\mathrm{O}_{2}^{--}$accumulation (Figure 6).
$15 \mathrm{mM}$ glucose-induced endothelial dysfunction and its modulation by propofol and PKC $\beta 2$ inhibitor

CGP53353, a highly selective inhibitor of PKC 32 , could decrease $15 \mathrm{mM}$ glucose-induced expression of NF- $\mathrm{kB}$ p65 protein in the nuclear extracts (Figure 7A, B), and the effect was similar to that of propofol. We also found that $15 \mathrm{mM}$ glucose-induced NF- $\mathrm{BB}$ activation was attenuated by CGP53353 (Figure 7C).

In addition, CGP53353 and propofol decreased $15 \mathrm{mM}$ glucose-induced expression of adhesion molecules to a similar extent (Figure 8). Consistently, $15 \mathrm{mM}$ glucose greatly induced mononuclear-endothelial adhesion, which 


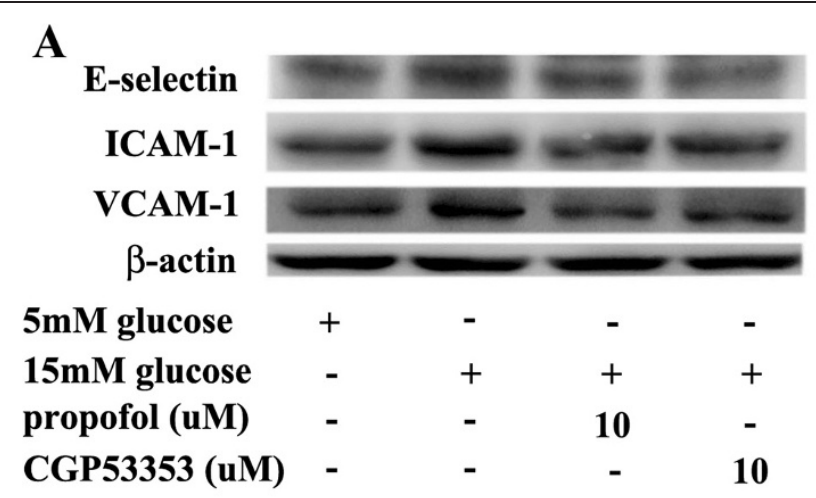

B

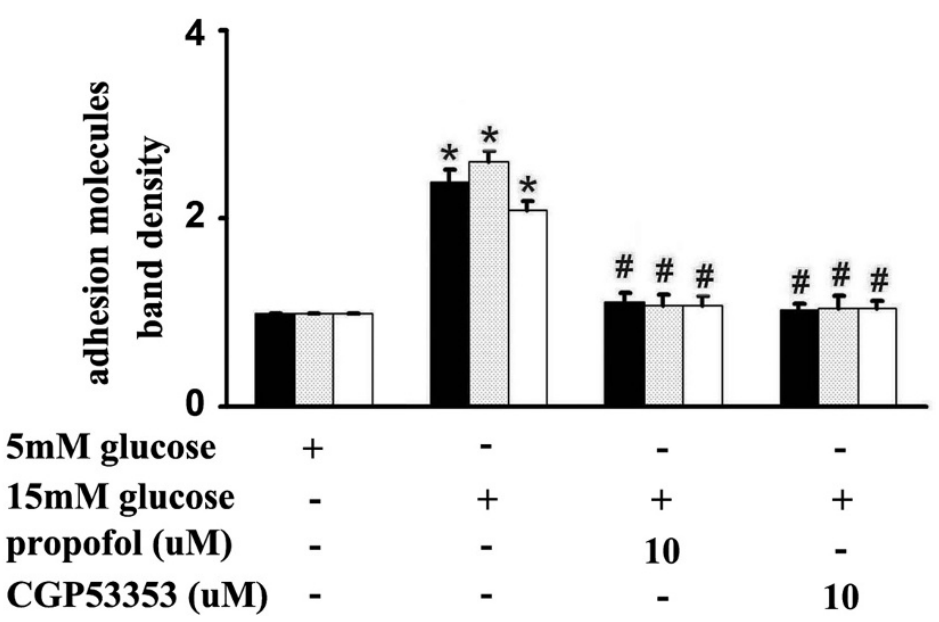

Figure 8 Effects of propofol and CGP53353 on 15 mM glucose-induced adhesion molecule expression. (A) Human umbilical vein endothelial cells were cultured in either $5 \mathrm{mM}$ glucose or $15 \mathrm{mM}$ glucose for $4 \mathrm{~h}$ with corresponding treatment. (B) Quantification of protein band density of adhesion molecules ( ${ }^{*} p<0.05$ vs. 5 mM glucose, $\# p<0.05$ vs. 15 mM glucose, $n=5$ ). Data were shown as mean \pm SD. - represents E-selectin, $\%$ represents ICAM-1, $\square$ represents VCAM-1.

was attenuated by propofol or CGP53353 pre-treatment (Figure 9).

\section{Discussion}

The main finding of the present study is that propofol could protect HUVECs against $15 \mathrm{mM}$ glucose-induced endothelial adhesion molecules expression and mononuclearendothelial interaction. Our data also suggested that the protective effects of propofol might be achieved by attenuating $\mathrm{O}_{2}^{-}$accumulation, inhibiting PKC $\beta 2$ ser $^{660}$ phosphorylation, PKC activity and NF- $\mathrm{kB}$ activation.

Hyperglycemia could up-regulate endothelial adhesion molecules expression, thus leading to the adhesion of monocytes to endothelial cells [3-5]. Many studies indicated that NF- $\mathrm{BB}$ signal pathway was involved in the hyperglycemia-mediated up-regulation of gene and protein expression of endothelial adhesion molecules, including VCAM-1, ICAM-1, and E-selectin [3-5,13-16]. These findings were consistent with our study (Figures 1, 2, 3, 4). Further, we suggested that PKC $\beta 2$ was involved in this process and its activation laid up-stream of NF- $\mathrm{kB}$ activation (Figure 5, 7, 8, 9). This was consistent with a previous study, which demonstrated that PKC 32 and NF- $\mathrm{KB}$ played a key role in high glucose-mediated up-regulation of VCAM-1 in vascular endothelial cells [17]. However, other pathways were also claimed to be responsible. Kim $\mathrm{S}$ et al. reported that high glucose-induced endothelial adhesion molecules expression was mediated through the p38 mitogen-activated protein kinase (MAPK) signaling pathway [18]. In our preliminary experiments, we examined the activity of p38 MAPK, but did not detect its activation in response to $15 \mathrm{mM}$ glucose (data not shown). We noticed that endothelial cells were treated with $25 \mathrm{mM}$ glucose for $24 \mathrm{~h}$ in their study, while we treated endothelial cells with $15 \mathrm{mM}$ glucose for $4 \mathrm{~h}$. One potential explanation for the discrepancy between their findings and 


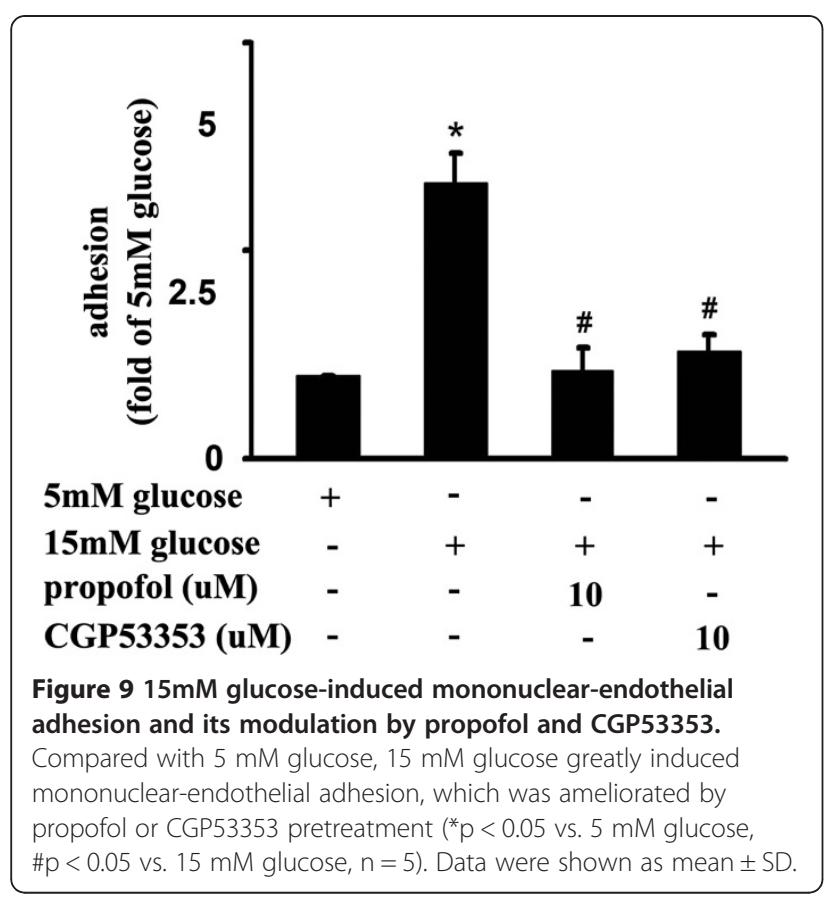

ours is that different concentration or duration of glucose treatment may up-regulate the expression of endothelial adhesion molecules through different pathways.

The necessity to regulate plasma glucose concentration to normal levels in perioperative hyperglycemic patients is debatable, because it may cause severe hypoglycemia and other serious adverse events [19]. As such, scientists are devoting to explore novel strategies, which may exert beneficial effects without tightly regulating plasma glucose levels. Recently, endothelial adhesion molecules have been widely considered to be potential targets for the effective treatment of high glucose-induced endothelial injury [20]. It has been shown that high glucose-induced mononuclear-endothelial cell adhesion and endothelial injury can be attenuated by several compounds, such as fasudil [21] and cannabidiol [22]. Interestingly, these compounds have the property to reduce superoxide generation and decrease endothelial adhesion molecules expression [21,22]. So, antioxidant may be a novel vascular protective strategy for hyperglycemic patients.

Propofol is an intravenous anesthetic agent which is widely used in clinical settings. Besides anesthetic properties, other characteristics of propofol have been widely studied in recent years. Propofol is chemically similar to endogenous antioxidant a-tocopheral (Vitamin E), and theoretically it should demonstrate similar properties [23]. Chen J et al. reported that propofol could attenuate the adhesion of monocytes to oxidative stress-activated HUVECs [10]. This was quite consistent with ours. In the present study, we found that propofol could significantly alleviate $15 \mathrm{mM}$ glucose-induced $\mathrm{O}_{2}^{-}$accumulation (Figure 6), endothelial adhesion molecules expression (Figure 2) and mononuclear-endothelial cell interaction (Figure 9). So we believe the antioxidative property of propofol is one of the main mechanisms for its protective effects on HUVECs.

The activation of NF- $\mathrm{KB}$ consists of several steps, starting with the degradation of IкB, a cytoplasmic inhibitor of NF$\kappa B$ [24]. Among I $\mathrm{KB}$ family, I $\mathrm{I} \mathrm{B} \alpha$ is the most widely studied [25]. IкB $\alpha$ degradation leads to the translocation of NF- $\mathrm{KB}$ from the cytoplasm compartment to the nuclear, where it could recognize and bind to the promoter of target genes and regulate the expression of these genes [26]. Studies have indicated that propofol could inhibit NF- $\mathrm{kB}$ activation in endothelial cells exposed to hydrogen peroxide [10] and lipopolysaccharide [27]. In the present study, we found that pre-treatment of cells with propofol attenuated $15 \mathrm{mM}$

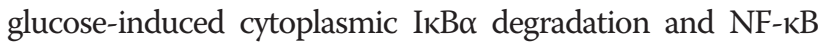
translocation (Figure 3). In addition, we demonstrated that propofol could inhibit $15 \mathrm{mM}$ glucose-induced endothelial adhesion molecules expression (Figure 2) and mononuclearendothelial cell interaction (Figure 9). These results strongly suggested that the beneficial effects of propofol on $15 \mathrm{mM}$ glucose-induced endothelial adhesion molecules expression may result from its inhibitory effects on NF- $\mathrm{kB}$ signal pathway.

It is of interest to determine the leading cause of PKC activation in response to high glucose. Gallo A et al., Gopalakrishna R et al. and Pricci F et al. reported that high glucose increased oxidative stress, which is responsible for the translocation and activation of PKC in vascular tissues [28-30]. It has also been reported that activation of PKC $\beta 2$ was associated with high glucose-induced vascular ROS generation [31] and high glucose-mediated nitric oxide reduction [32]. In the present study, we found propofol could attenuate $15 \mathrm{mM}$ glucose-induced $\mathrm{O}_{2}^{-}$accumulation (Figure 6). Consistently, our previous study showed that propofol could restore high glucose-mediated $\mathrm{O}_{2}^{-}$accumulation and nitric oxide reduction via re-coupling endothelial nitric oxide synthase [33]. Accordingly, we suggested that the antioxidative effect of propofol is a potential mechanism responsible for the beneficial effect on high glucosemediated PKC activation and mononuclear-endothelial adhesion.

In a recent study, vascular healing responses were described after drug-eluting stent implantation in experimental models, employing everolimus or paclitaxel [34]. In these models, anesthesia was achieved with propofol. We may raise the assumption that the obtained favorable effects were at least partially due to propofol. Further studies in in vivo models are necessary to verify this hypothesis.

This study has some limitations. First, the study was carried out in HUVECs, which is an in vitro system. It differs from in vivo settings, especially when drug effectiveness 
and toxicity is considered. Secondly, we did not investigate the effect of propofol and high glucose on mononuclear. So further experiments are required to determine whether the effect of propofol on high glucose-induced mononuclear-endothelial interaction is mediated by endothelial cells, mononuclear cells, or both.

\section{Conclusions}

In summary, the present study suggested that $15 \mathrm{mM}$ glucose, by inducing $\mathrm{O}_{2}^{-}$accumulation, $\mathrm{PKC} \beta 2 \mathrm{Ser}^{660}$ phosphorylation and PKC activation, NF- $\mathrm{KB}$ activation, upregulated endothelial adhesion molecules expression and augmented mononuclear-endothelial interaction. More importantly, our study demonstrated that propofol, via decreasing $\mathrm{O}_{2}^{-}$accumulation, down-regulating PKC $\beta 2$ Ser ${ }^{660}$ phosphorylation and PKC activity, inhibiting NF- $\mathrm{KB}$ activation, attenuated $15 \mathrm{mM}$ glucose-induced endothelial adhesion molecules expression and mononuclear-endothelial adhesion. Our data implied the potential advantage of the administration of propofol to provide sedation in hyperglycemic patients in operation room or in post anesthesia care unit.

\section{Abbreviations \\ E-selectin: Endothelial selectin; ICAM-1: Intercellular adhesion molecule 1; VCAM-1: Vascular cell adhesion molecule 1; NF-kB: Transcription factor nuclear factor kappa B; HUVECs: Human umbilical vein endothelial cells; IKBa: Inhibitory subunit of NF-kBa; PKC: Protein kinase C; ROS: Reactive oxygen species; $\mathrm{O}_{2}$ : Superoxide anion.}

\section{Competing interests}

The authors declare no conflicts of interest.

\section{Authors' contributions}

$\mathrm{MZ}$ conducted the experiments and contributed to the study implementation, statistical analysis, interpretation, and the preparation of the manuscript. JC conducted the experiments and contributed to the study design, implementation, and the preparation of the manuscript. Both MZ and $\mathrm{JC}$ contributed equally to this paper. $\mathrm{HJ}$ helped to conduct the experiments. CM supervised the study conduction and contributed to the study design, implementation, statistical interpretation, the preparation and finalization of the manuscript. All authors approved the final manuscript for publication.

Received: 24 October 2012 Accepted: 14 December 2012 Published: 11 January 2013

\section{References}

1. Werb MR, Zinman B, Teasdale SJ, Goldman BS, Scully HE, Marliss EB: Hormonal and metabolic responses during coronary artery bypass surgery: role of infused glucose. J Clin Endocrinol Metab 1989, 69:1010-1018.

2. Walts LF, Miller J, Davidson MB, Brown J: Perioperative management of diabetes mellitus. Anesthesiology 1981, 55:104-109.

3. Morigi M, Angioletti S, Imberti B, Donadelli R, Micheletti G, Figliuzzi M, Remuzzi A, Zoja C, Remuzzi G: Leukocyte-endothelial interaction is augmented by high glucose concentrations and hyperglycemia in a NF-kB-dependent fashion. J Clin Invest 1998, 101:1905-1915.

4. Marfella R, Esposito K, Giunta R, Coppola G, De Angelis L, Farzati B, Paolisso G, Giugliano D: Circulating adhesion molecules in humans: role of hyperglycemia and hyperinsulinemia. Circulation 2000, 101:2247-2251.

5. Baumgartner-Parzer SM, Wagner L, Pettermann M, Gessl A, Waldhausl W: Modulation by high glucose of adhesion molecule expression in cultured endothelial cells. Diabetologia 1995, 38:1367-1370.
6. Son SM, Whalin MK, Harrison DG, Taylor WR, Griendling KK: Oxidative stress and diabetic vascular complications. Curr Diab Rep 2004, 4:247-252.

7. Ceriello A: New insights on oxidative stress and diabetic complications may lead to a "causal" antioxidant therapy. Diabetes Care 2003, 26:1589-1596.

8. Lee YJ, Kang DG, Kim JS, Lee HS: Lycopus lucidus inhibits high glucoseinduced vascular inflammation in human umbilical vein endothelial cells. Vascul Pharmacol 2008, 48:38-46.

9. Kwon KB, Kim EK, Lim JG, Shin BC, Song YS, Seo EA, Ahn KY, Song BK, Ryu $D G$ : Sophorae radix extract inhibits high glucose-induced vascular cell adhesion molecule-1 up-regulation on endothelial cell line. Clin Chim Acta 2004, 348:79-86.

10. Chen J, Gu Y, Shao Z, Luo J, Tan Z: Propofol protects against hydrogen peroxide-induced oxidative stress and cell dysfunction in human umbilical vein endothelial cells. Mol Cell Biochem 2010, 339:43-54.

11. Mathy-Hartert M, Deby-Dupont G, Hans P, Deby C, Lamy M: Protective activity of propofol, Diprivan and intralipid against active oxygen species. Mediators Inflamm 1998, 7:327-333.

12. Cai S, Khoo J, Channon KM: Augmented BH4 by gene transfer restores nitric oxide synthase function in hyperglycemic human endothelial cells. Cardiovasc Res 2005, 65:823-831.

13. De Martin R, Hoeth M, Hofer-Warbinek R, Schmid JA: The transcription factor NF-KB and the regulation of vascular cell function. Arterioscler Thromb Vasc Biol 2000, 20:E83-E88.

14. Schindler U, Baichwal VR: Three NF-кB binding sites in the human Eselectin gene required for maximal tumor necrosis factor a-induced expression. Mol Cell Biol 1994, 14:5820-5831.

15. Shu HB, Agranoff AB, Nabel EG, Leung K, Duckett CS, Neish AS, Collins T, Nabel GJ: Differential regulation of vascular cell adhesion molecule 1 gene expression by specific NF-KB subunits in endothelial and epithelial cells. Mol Cell Biol 1993, 13:6283-6289.

16. Ledebur HC, Parks TP: Transcriptional regulation of the intercellular adhesion molecule-1 gene by inflammatory cytokines in human endothelial cells. Essential roles of a variant NF-KB site and p65 homodimers. J Biol Chem 1995, 270:933-943.

17. Kouroedov A, Eto M, Joch H, Volpe M, Lüscher TF, Cosentino F: Selective inhibition of protein kinase Cbeta2 prevents acute effects of high glucose on vascular cell adhesion molecule-1 expression in human endothelial cells. Circulation 2004, 110:91-96.

18. Kim SW, Kim CE, Kim MH: Flavonoids inhibit high glucose-induced upregulation of ICAM-1 via the p38 MAPK pathway in human vein endothelial cells. Biochem Biophys Res Commun 2011, 415:602-607.

19. Lipshutz AK, Gropper MA: Perioperative glycemic control: an evidencebased review. Anesthesiology 2009, 110:408-421.

20. Lutters BC, Leeuwenburgh MA, Appeldoorn CC, Molenaar TJ, Van Berkel TJ, Biessen EA: Blocking endothelial adhesion molecules: a potential therapeutic strategy to combat atherogenesis. Curr Opin Lipidol 2004, 15:545-552.

21. Li H, Peng W, Jian W, Li Y, Li Q, Li W, Xu Y: ROCK inhibitor fasudil attenuated high glucose-induced MCP-1 and VCAM-1 expression and monocyte-endothelial cell adhesion. Cardiovasc Diabetol 2012, 11:65.

22. Rajesh M, Mukhopadhyay P, Bátkai S, Haskó G, Liaudet L, Drel VR, Obrosova IG, Pacher P: Cannabidiol attenuates high glucose-induced endothelial cell inflammatory response and barrier disruption. Am J Physiol Heart Circ Physiol 2007, 293:H610-619.

23. Aarts L, van der Hee R, Dekker I, de Jong J, Langemeijer H, Bast A: The widely used anesthetic agent propofol can replace alpha-tocopherol as an antioxidant. FEBS Lett 1995, 357:83-85.

24. Pahl HL: Activators and target genes of Rel/NF-kappaB transcription factors. Oncogene 1999, 18:6853-6866.

25. Spiecker M, Peng HB, Liao JK: Inhibition of endothelial vascular cell adhesion molecule-1 expression by nitric oxide involves the induction and nuclear translocation of IkappaBalpha. J Biol Chem 1997, 272:30969-30974.

26. Gerritsen ME, Williams AJ, Neish AS, Moore S, Shi Y, Collins T: CREB-binding protein/p300 are transcriptional coactivators of p65. Proc Natl Acad SCi USA 1997, 94:2927-2932

27. Gao J, Zhao WX, Zhou L, Zeng BX, Yao SL, Liu D, Chen ZQ: Protective effects of propofol on lipopolysaccharide-activated endothelial cell barrier dysfunction. Inflamm Res 2006, 55:385-392.

28. Gallo A, Ceolotto G, Pinton P, lori E, Murphy E, Rutter GA, Rizzuto R, Semplicini A, Avogaro A: Metformin Prevents Glucose-Induced Protein Kinase C-beta2 Activation in Human Umbilical Vein Endothelial Cells Through an Antioxidant Mechanism. Diabetes 2005, 54:1123-1131. 
29. Gopalakrishna R, Jaken S: Protein kinase $C$ signalling and oxidative stress. Free Radic Biol Med 2000, 28:1349-1361.

30. Pricci F, Leto G, Amadio L, lacobini C, Cordone S, Catalano S, Zicari A, Sorcini M, Di Mario U, Pugliese G: Oxidative stress in diabetic-induced endothelial dysfunction involvement of nitric oxide and protein kinase C. Free Radic Biol Med 2003, 35:683-694.

31. Rask-Madsen C, King GL: Proatherosclerotic mechanisms involving protein kinase $\mathrm{C}$ in diabetes and insulin resistance. Arterioscler Thromb Vasc Biol 2005, 25:487-496.

32. West MB, Ramana KV, Kaiserova K, Srivastava SK, Bhatnagar A: L-Arginine prevents metabolic effects of high glucose in diabetic mice. FEBS Lett 2008, 582:2609-2614.

33. Zhu M, Chen J, Tan Z, Wang J: Propofol protects against high glucoseinduced endothelial dysfunction in human umbilical vein endothelial cells. Anesth Analg 2012, 114:303-309.

34. Sheehy A, Hsu S, Bouchard A, Lema P, Savard C, Guy LG, Tai J, Polyakov I: Comparative vascular responses three months after paclitaxel and everolimus-eluting stent implantation in streptozotocin-induced diabetic porcine coronary arteries. Cardiovasc Diabetol 2012, 11:75.

doi:10.1186/1475-2840-12-13

Cite this article as: Zhu et al:: Propofol protects against high glucose-

induced endothelial adhesion molecules expression in human umbilical vein endothelial cells. Cardiovascular Diabetology 2013 12:13.

\section{Submit your next manuscript to BioMed Central and take full advantage of:}

- Convenient online submission

- Thorough peer review

- No space constraints or color figure charges

- Immediate publication on acceptance

- Inclusion in PubMed, CAS, Scopus and Google Scholar

- Research which is freely available for redistribution 